\title{
NORMS AND PRACTICES OF POLYLINGUAL BEHAVIOUR: A SOCIOLINGUISTIC MODEL
}

\author{
Jens Normann Jørgensen ${ }^{1}$ and Somogy Varga ${ }^{2}$ \\ ${ }^{1}$ University of Copenhagen, ${ }^{2}$ University of Osnabrück, and \\ ${ }^{2}$ University of Copenhagen
}

\begin{abstract}
This paper discusses the notion of language in relation to the notion of a language. We argue that the concept of languages as neatly separated, countable units is an ideological construction. This ideological construction served the European nation states well during the Romantic period and later, for instance during Colonialism (e.g. Heller 2007, Makoni and Pennycook 2006). With growing internationalization, however, this concept of languages has become increasingly at odds with the linguistic experience of speakers throughout Europe. In fact the notion of languages, for instance as separable from dialects, has never been accepted by sociolinguistics. Any specific notion of a language, say Dutch, is a sociocultural construction, and it is only real at the level of norms. At the level of language use we can not maintain these concepts of languages. As an alternative idea of language we propose that descriptions and analyses of language use must be based, not on "languages", but on features, and the focus must be in the individual (Hudson 1996).
\end{abstract}

Keywords: languaging, polylingualism, language norms, late modern urban youth language

\section{Introduction: language, languages, and languagers}

Humankind is arguably the only species with language. Humans use language to obtain their goals, to change the world. The intentional use of language to further one's ends is languaging (see Jørgensen 2004a). Languaging is characterized by the use of language, understood as different from the concept of languages. In a sense, language characterizes the species and may therefore be considered "natural". But in an important sense, languages are not natural, and this has implications for a sociolinguistic under- 
standing of bilingualism and the parallel terms of trilingualism, etc. This is why, instead of the givenness of language, the term "languaging" also emphasizes the constitutive role of the agency of speakers.

However, languages are not only considered as natural, but also often as something akin to "natural kinds". For instance, bilingualism is traditionally defined as a relationship between an individual (or a group of individuals) and two different languages. Behind the organization of classes, in schools and at universities all over the world, which carry labels such as "French" and "English", lies the same perspective on different languages. Languages are considered as separate, distinguishable packages which can be counted: one, two, three, etc. Against such a picture, sociolinguistics has pointed out long ago that it is not possible to determine the linguistic borderline between, for instance, German and Dutch. We can not determine, except by arbitrary choice, exactly what is German and what is Dutch (e.g. Romaine 1994: 135, Hudson 1996: 34). The borders between languages will, at best, be either arbitrary or fuzzy if we want to define them on the basis of linguistic difference. In other words, for empirical reasons we should reject the ontological idea that languages can be understood as akin to "natural kinds", thus closed entities that can be classified and counted: one, two, etc. But besides, this empirical argument could be additionally strengthened by involving Jan Hacking's work on the philosophy of science. The idea would be to emphasize that languages are "interactive kinds" (Hacking 1999). With interactive kinds, the fact of classification has changing effects on what is classified and on the related institutions. What is classified, then, becomes a "moving target". If this is right, then we can say that languages are not just "fuzzy" in the empirical sense, but also per se.

Also on a slightly more particular level of a single language, such a "static" view of languages inevitably runs into difficulties. This is because language is - among linguists as well as non-linguists - without doubt perceived as sets of features, i.e. conventions which are believed to somehow belong together. But while there is widespread agreement (at least among nonsociolinguists) that such a phenomenon as "the Danish language" exists, there is very little agreement of precisely what features belong together in any given language, for instance in what is called "Danish". Therefore there are intense public discussions 
about what linguistic items belong to "the Danish language", and what features do not. In addition to this, there is widespread agreement that words have "correct" pronunciations, that there are "correct" words and "incorrect" words, that there is "correct" grammar and "incorrect" grammar, etc. Nevertheless, it is still a problem for speakers to agree what is correct and what is not. Speakers do not agree what features belong to the "correct language".

Again, we need to emphasize that this is not a practicalempirical problem that could be solved by applying a more fine-grained method. Instead such problems simply cannot be solved on the basis of linguistic distinctions. This is because a language (i.e. as opposed to the uncountable noun language) besides containing a specific set of features which distinguishes it from all other languages, i.e. all other sets of features, is also to a wide extent both a sociocultural construct and an ideological construct. We could say that while "languages" are sociocultural constructs, they first become ideological constructs when classifications are being put to work in larger, political networks of power. Turning to the work of Makoni and Pennycook (2006), we can demonstrate the usefulness of such a distinction. Makoni and Pennycook (2006: 2) point out that the Europe-based development of national romanticism has gone together with the development of a notion of languages as separate entities: "Alongside or, rather, in direct relation with the invention of languages, therefore, an ideology of languages as separate and enumerable categories was also created". Johann Gottfried Herder's philosophy of language has among its numerous other contributions to the history of thought, contributed to this process of reflection that resulted in the invention of both the idea of "languages" and of linguistically constituted people (das Volk). Of course, such a conceptualization of language (and people) invites an ideological use. Such an ideological turn can be seen in Makoni and Pennycook, who observe that the concept of languages as opposed to language was brought to South Asia and Africa by European colonizers. The colonizers forced the ideological concept on the colonized. Makoni and Pennycook note that sociolinguists who lament the fate of "endangered languages" or advocate "linguistic human rights" indeed can be seen as working in this European romanticist ideological tradition. They add that "the metadiscursive regimes that emerged to describe languages are 
part of a process of epistemic violence visited on the speakers of those languages as they were called into existence" (Makoni and Pennycook 2006: 21). In this way, we can maintain the difference between "language" as an ideological construct, and "language" as a sociocultural construct.

While such a construct has only weak support in the practice of language users, particularly among late modern urban youth, ideologically, however, the notion of "a language" as entities which can be neatly separated and distinguished between is very strong.

If we understand, organize, and draw on those resources as belonging to whole, bounded systems we call "languages", it is because that notion makes sense in the context of the ways language has been bound up in ideologies of nation and state since the nineteenth century. (Heller 2007: 1)

The ideological strength of this notion is so great that it is almost impossible to challenge it, for instance among decision makers, education planners, gatekeepers, etc. throughout the modern or late modern world. Also, we must take account of the fact that people, the language users, think of features as belonging to sets of features, and that they call these sets of features languages (or dialects, etc., or specific names such as Russian, Scottish English, or schwäbisch, etc.) In other words, this is what sociolinguists have attempted to find cover terms for, such as variety or code. We will therefore still need terms for these socioculturally constructed sets of features. Since there is only a slim basis in real life language use for these concepts, we can not distinguish between codes, be they perceived as languages or as dialects, except when we consider them precisely as sociocultural constructions. As such constructions, a classification of these entities only makes sense if we think of them in terms of what Weber called "ideal-types", thus as unified thought-constructs that draw conceptual boundaries around otherwise fuzzy phenomena, or, in Hudson's terms "proto-types" (1996: 88). In this sense it may make sense to think of Danish and Norwegian as separate languages, and to think of Kurmanci and Surani as different dialects of the same language, and all of them as different codes. 
A code is a sociocultural (ideological) construction considered to comprise a specific set of linguistic features which sets it apart from all other sets of features.

This leads to the observation that speakers do not use "languages". What they use in interaction are features. Features are used in the shape of units (words, morphemes, sounds, fixed expressions, etc.) and regularities (so-called "rules" of grammar, etc.) Along the same line of thinking, what people learn in schools are not "languages", but features. In classes which carry the label "Turkish" the students are, for instance, taught the word kitap. They learn this, and they learn that it combines with a plural marker, the flexive -lAr. Such features are internalized by the students (one way or another). But the students also learn that these features are considered to belong to a category, a set of features. This category of linguistic features has a name, in casu "Turkish". As students acquire the features that are taught to them, they additionally learn about these features how they are socioculturally associated with sets of features, categories. These categories are usually called "languages" when they are explicitly taught in the educational systems of this world. Other sets of features, categories, are, as we have seen, labelled "dialects", but they are rarely taught in schools. They are codes in the same sense, nonetheless.

\section{Code-switching}

This has implications for the study of code-switching. "Different languages" are different as sociocultural constructions, but not necessarily - and certainly not consequently - in the linguistic practices of speakers. Speakers use features, not languages, not dialects, not codes. The features are, however, socioculturally associated with codes, and speakers may use this fact - they may juxtapose features which are associated with different codes. Such a practice may amount to code-switching. Code-switching as an interactional phenomenon is defined by Auer as

a relationship of contiguous juxtaposition of semiotic systems, such that the appropriate recipients of the resulting complex sign are in a position to interpret this juxtaposition as such. (Auer 1995: 116) 
With the concept of codes as sociocultural constructions it is possible to distinguish between codes, precisely when we base our analysis on the association of features with sets of features (codes). When features are juxtaposed which are associated with different socioculturally constructed sets of features (and the interlocutors are in a position to interpret the juxtaposition as such), we are dealing with code-switching. With this we can define code-switching.

A code-switch is a juxtaposition of linguistic features which are associated with different codes (socioculturally determined sets of features) such that the involved interlocutors are in a position to interpret the juxtaposition as such.

This definition points to a problem with terms such as "bilingualism". The term "monolingualism" covers the phenomenon that an individual knows and uses features which belong to one set of features, one language - and only one. The term "bilingualism" is similarly a term for the phenomenon that an individual knows (or "commands" or "has access to") features belonging to two different sets of features, two languages - and only two. The term multilingualism describes the phenomenon that an individual human being knows features from more than two sets of features. These terms all take several things for granted. Firstly, they take it for granted that the linguistic features commanded by the individual are bundled into neat separate packages. As we have seen, this is already in itself a claim which can not be upheld. Secondly, and more controversially, there is a problem with the relationship between the speakers and the sets of features. It is taken for granted that the individual speaker "knows" one, two or more languages, that the language user is "able to speak" the languages, or somehow commands more than just a minimum of the relevant languages. The criteria of knowing or commanding languages are vague at best. This fact has led to long discussions about criteria of bilingualism which was termed as "real" or "balanced" or in other ways directly measurable. Thirdly, the terms take it for granted that the behaviour of the language user at any given time can be characterized quite simply as unmarked, as code-switching, or as borrowing. A given utterance is unmarked if it uses features from only one language. If the utterance in- 
volves features associated with more than one language, one of two descriptions holds. The speaker "code-switches", or the speaker "borrows". The features borrowed from "one language" into "another language" are considered alien to the loaning language until some adjustments have taken place, phonetically, morphologically, or otherwise.

This is precisely where the concepts become problematic. In real life, i.e. in the way languages work among people, features do not bundle nicely together into sets of features. Some features accompany very different groups of other features (the word fuck may appear alongside words such as regeringen (Danish for the government), and it may appear alongside words such as le police (French for the police); but very few other words may appear in exactly these two surroundings). On the other hand, there are probably very many words in the world which can be used together with fuck, namely any word, whatever language it is ascribed to, when it denotes some kind of authority: fuck sini tole, fuck kowwouktys sipannanlo. In other cases features may appear in certain specific surroundings, and we will not be able to identify these features as belonging together with any specific (set of) features and not others. Hinnenkamp (2003: 20) has a particularly illustrative example of this. An adverbial construction frequently used among young language users in Germany is the sequence [ondan] (in phonetic transcription) which could be identified as the German und dann, or as the Turkish ondan (Hinnenkamp 2003: 20) both of which can translate into and then). The spoken utterance gives us no opportunity to determine a particular association of [ondan] with one of the two "languages" more than the other. Similarly we can not describe the language behaviour of young late modern urban language users in terms of "monolingualism", "bilingualism", etc. It is not so that the speakers either use one language at a time or code-switch. Rampton (1995) shows how adolescents in a youth club use features associated with a range of different categories (such as "Caribbean Creole", "Cockney English", "Stylized Asian English", "Panjabi", and "Bengali") regardless of the fact that none of the speakers "know" or "command" all of these languages.

As with Hinnenkamp's [ondan] example speakers may "use" two languages simultaneously - in one and the same word, in one and the same syllable, in one and the same sound. Secondly, they may also use features which are not part and parcel 
of the neat packages into which features are categorized (for instance the "stylized Asian English" documented and analyzed by Rampton 1995). Thirdly, the young language users may use words without borrowing them in the traditional sense - the words are not alien to their language behaviour, but at the same time the words are not adjusted to their mother tongue (or any language they are considered to "know") either. This is a phenomenon which is in fact not restricted to young speakers (as documented by Jacquemet 2005).

This emphasizes that speakers use features and not languages, not codes. The features are associated with codes, and therefore the features may become the subject of evaluations. Different codes carry prestige at different levels. Perhaps it is more precise to say that speakers taken to be native speakers of different codes carry prestige at different levels. These differences in prestige spill over into the evaluations of specific features. The speakers may refer to, exploit, and comment on these evaluations in their interaction. Indeed, speakers may oppose generally held beliefs and evaluations and re-evaluate codes as well as features. Similarly codes and their speakers may become the objects of stereotyping, such as the stinginess of Scottish speakers, the German roughness, and the naivety of the (female) Southern U.S. American English speaker.

It is a simple observation that the practice of stereotyping and referring to evaluations of codes and their speakers is not restricted to people who are categorized as "bilingual" or "multilingual". It is a common observation that so-called native speakers of a language know (or have access to) a range of styles, registers, or even dialects of their mother tongue. This may be used for specific effects. One such effect is the laughter caused by the use of rural dialects in "jokes" which are actually long stories without points - except for the use of a rural dialect (Scottish English, Texas English, Jutland Danish, Lazca Turkish, etc.). Speakers may also self-style while indirectly referring to evaluations of codes. The English-speaking young man who refuses his colleague a loan of $10 £$, and does so with an emphatic Scottish-accented I have no money left for fun this month refers to the stereotype of the stingy Scot. Sometimes styles are represented in excess stereotyping, such as Hollywood German, or the English spoken by Russian characters in James Bond movies. Speakers have access to and may use the stereotypes in the same 
way as they use value associations with other features such as the academic prestige carried by quotes in Latin.

\section{Norms of language use}

There are not only specific concepts about "different" languages in society at large, there are also strong norms for the choice of features among these "different" languages. Educational systems and gatekeepers at least in Europe and North America not only subscribe to the concept of languages as separate entities, but also to the norm that speakers should keep languages separate in the practices.

The double (or multiple) monolingualism norm: persons who command two (or more) languages should at any given time use one and only one language, and they should use each of their languages in a way that does not in principle differ from the way in which monolinguals use that same language (see also Jørgensen 2001: 121).

Whether speakers also believe that certain features should belong together and only be used together, is a sociolinguistically important question. It goes without saying that we can observe young language users massively violating this norm and its more radical version which states that monolingualism is normal and bilingualism an aberration from normality (statements to this effect can be found for instance in Danish official educational documents, e.g. Undervisningsministeriet 1992: 19-20). Monolingualism norms insist on the concept of languages as separable packages of linguistic features. Languages may borrow from each other, and the borrowings may become permanent (as opposed to "nonce loans" or "ad-hoc loans"). Sociolinguists such as Gumperz (1982) and Boyd (1985) recognize the typical behaviour of many "bilingual" individuals who use features from both languages in the same production. In the view of both Gumperz and Boyd speakers employ the very differences, including evaluations and stereotypes, in their linguistic resources, and speakers may further decide to employ these resources for specific effects. Monolingual behaviour remains a distant norm which does not affect the speakers very much. 
The Køge Project, a study of the linguistic development of Turkish-Danish grade school students (see for instance Jørgensen $2004 b)$ provides an illustration. On two different occasions students involved in a cutting and pasting task were looking for a pair of scissors. In one case the students said Makasim yok, makas nerede, giv mig så en saks. In the other case the words were Jeg har ikke nogen saks, hvor er der en saks, makas ver. When translated into English, these two utterances are completely identical: I don't have a pair of scissors, where is there a pair of scissors, give me a pair of scissors. However, the first utterance begins with words associated with the language called "Turkish" and ends with words associated with the language called "Danish". In the second utterance, the order is reversed. Since "Turkish", in Gumperz' (1982) terms, can be taken to be a "we-code", and "Danish" a "they-code" to the students, these two utterances may be very different. The first changes the context from a cosy one (characterized by "Turkish") into an efficient, but also arrogant one (characterized by "Danish"). The second utterance changes the context from a typical school one ("Danish"), into a private and more solidarity-oriented one ("Turkish"). It would take us too far to discuss how we analyze utterances sequentially to obtain such understandings, suffice it here to observe that speakers have resources to express these fine distinctions. In this light speakers can be said to follow an integrated bilingualism norm.

The integrated bilingualism (or multilingualism) norm: persons who command two (or more) languages may employ their full linguistic competence in the languages they know at any given time adjusted to the needs and the possibilities of the conversation, including the linguistic skills of the interlocutors.

This norm depends on the same view of languages as the monolingualism norm, i.e. languages can be separated into entities which can be counted. The difference between the two norms lies in the prescriptions for the use of the features belonging to the languages. The integrated bilingualism can not handle the behaviour observed by Rampton (1995), i.e. speakers' frequent use of features which are ascribed to languages from which the speakers know only very few features. Such behaviour has been described in a range of different studies (Quist 2000, Nortier 
2001, Sweetland 2002, Christensen 2004). Such behaviour can be described by the polylingualism concept (for instance, Jørgensen 2010, Møller and Jørgensen 2008).

The polylingualism norm: language users employ whatever linguistic features are at their disposal to achieve their communicative aims as best they can, regardless of how many features they know which are associated with the involved languages; this entails that the language users may know - and use - the fact that some of the features are perceived by other speakers as not belonging together.

Behaviour which follows the polylingualism norm may in other words involve features from languages "which the speaker does not know very well", as it is traditionally formulated. The polylingualism norm is different from the multilingualism norm in this respect. The multilingualism norms take it for granted that the speakers "know" or "command" (with the great variation in what these terms mean) the involved languages. As we have seen: with the multilingualism norm follows the concept of "a language" which assumes that languages can be separated also in use, and in this view it is also possible to determine whether an individual "knows" a language or "has" a language. The term multilingual covers the (more or less "full") command of several languages, whereas the term polylingual also allows for the integration of features ascribed to other languages.

Hewitt (1991: 30) has suggested a view of culture which parallels this understanding of language. He distinguishes between multiculturalism and "polyculture". He understands multiculturalism as "a pluralist order of discrete patches of culture, all, somehow, "equally valid" within the polity". On the other hand he defines polyculture, which is "a collection of cultural entities that are not (a) discrete and complete in themselves; (b) that are not in any sense "intrinsically" equal; and (c) are active together and hence bound up with change". Hewitt illustrates his concept of polyculture with pre-historical cave paintings. Their many layers of additions and superimposed features make it impossible to determine exactly what elements belong together in time (and painter). The paintings are his metaphor for polycultural phenomena, "in this fluid chaos" (Hewitt 1991: 29). We may identify 
each individual phenomenon in late modern culture, but not be able to define its totality in terms of their relationships to separate identifiable cultures (in the plural).

\section{Polylingual behaviour}

We are often unable to identify how features employed in polylingual language use combine, and they certainly do not combine into nice packages of recognizable features. To which linguistic set of features the individual features "really" belongs is immaterial, and the discussion may be pointless (as with Hinnenkamp's [ondan] example). The point is that language users may know with what "languages" the feature they use are generally associated. Sometimes they may not know. A word usually ascribed to, for instance, Kurmanci may be used among a group of young Copenhageners. Some participants in a given conversation may understand this word as a signal of a specifically Kurdish minority status. Other participants who do not recognize this particular word as something generally associated with Kurmanci may understand the use as a signal of membership in the particular youth group, and only that.

We can describe and analyze polylingual behaviour more precisely and directly as combinations of features than as combinations of languages. Some speakers employ, side by side, different features which are separated by some other speakers, and which should, according to older norms, be separated. As we have observed, this type of behaviour is not restricted to late modern urban youth. The Englishman may use both the Scottish accent and a single word from German (for instance heraus) in the same utterance, even without knowing very much else which is ascribed to German. A Køge, Denmark student may use the utterance vir prudens non contra ventum mingit (Latin: a wise man does not pee against the wind) in order to explain, for instance her timid behaviour in a confrontation with a teacher. She may even know what it means, but know nothing else which is considered Latin. This utterance can not very well be said to be a "loan" into Danish, and the student can not very well be described as a learner of Latin. However, she exploits the evaluation of Latin as the language of learning, of Academia - at least she may do so to the extent that the utterance is meant to be heard by a teacher. 
On the other hand, she may also exploit the evaluation of Latin which, thanks to the popularity of a series of comic books (Astreix and the Gauls), places such quotes as slightly oppositional youth language.

The Køge project also provides examples of feature use which involves different codes which are considered to belong to the "same language". Erol den duer altså ikke derinde der er noget galt (Danish for Erol it does not work in there, something is wrong). The girl who says this pronounces the word galt with an exaggerated stød stereotypically associated with Sealand Danish. Exaggerated Sealand Danish usually triggers the laughter that is used for rural dialects in many places. Heavy Sealand Danish is used in movies and on stage to stereotype figures as narrow-minded and less than bright. The ultimate comical figure in Danish theater (Jeppe på Bjerget) speaks a Sealand Danish. No living person speaks such a Sealand Danish any more. By using this marked pronunciation the speaker in the Køge example takes some of the power out of her utterance which is, on the surface, a criticism of the work done by Erol. The effect is that the utterance sounds milder than otherwise (and it is reacted upon accordingly, but that is a different matter).

In other words, the use of features which are associated with codes that the speakers are not considered to know or command very well, may be eloquent, equivocal, and sharply pointed. Such behaviour is much more frequent than textbooks let us know. In a sense most late modern speakers perform such practices. In principle there is no difference between, on the one hand, using features associated with Sealand Danish together with features ascribed to standard Copenhagen Danish, and on the other hand, using features ascribed to Swahili together with features ascribed to West Greenlandic.

In late modern cities of the $2000 \mathrm{~s}$, the range of features to which especially young people have daily access, is much wider than just 30 years ago. Young speakers integrate features associated with languages which used to be considered exotic. This phenomenon has caused the negative reactions one could expect. Young people who eloquently handle features the existence of which older people don't even know are usually not rewarded for their linguistic agility. This is so because the monolingualism norms are strong in the educational systems and among gatekeepers. The ideological view of what is "a language" completely 
dominates educational thinking, even to the extent of disallowing code-switching (code-switching is routinely assumed to have negative effects on the learning of "languages", see Arnfast and Jørgensen 2003).

\section{Polylingual languaging - examples}

In this section we present examples of the polylingual behaviour of late modern youth. They are from the Køge project (see also Jørgensen 2001 and Jørgensen 2010) and involve young men around 16 years old, in grade 9 of a public school in Køge, Denmark. They are all Turkish-Danes. For simplicity we use formulations such as "this word is Turkish", which should of course be taken to mean "this word is a feature associated with the socioculturally constructed set of features which has been given the name Turkish". The main provider of examples is the boy Erol.

The first example is an utterance produced by Erol in which he says ah bak kim var halal og farvel (English: oh look who is there, halal and goodbye). The words ah bak kim var belong to Turkish. The greeting halal og farvel includes the word halal which has been loaned into Danish recently, and the Danish word farvel which means goodbye. This is a pun referring to the Danish word hallo which is a welcoming greeting (hello and goodbye). It is pronounced in a typical late modern urban youth style. This style is stereotypically related to male, young, Moslem minority Danes. The word halal, in addition, denotes a Moslem phenomenon which is the target of a range of stereotyping attitudes in the public debate in Denmark. The evaluations involved in the remark ah bak kim var halal og farvel are therefore complex, and there are features ascribed to at least three different codes involved.

(Turkish in italics, Danish in recte, everything else underlined), 9. grade conversation from the Køge Project:

Erol: ah bak kim var halal og farvel [ah, look who is here, halal and goodbye].

Hüseyin: Tæskeholdet [the Gang of Thugs]. 
Erol: hi hi hi halal og farvel Tæskeholdet [the Gang of Thugs]. Erol: Murat har lige slået en skid \# o adamın xxx aynı senin gibi [Murat has just farted \# that man xxx just like you].

Bekir: Tæskeholdet' $u$ bir bana ver hele [give me the Gang of Thugs].

Erol: al len senin olsun istiyor musun [take it, it's yours if you want it].

His use of styles stereotypically related to minority groups is not limited to Danish. The second example is an utterance which he produces later in the same conversation. In this he says where are you going today. This utterance is pronounced with an exaggerated retroflexion of the d-sound in -day and a front tongue r-sound in where, i.e. with phonetic features which are characteristic of stylized Indian English. This is not his only way of speaking English. He has the utterance Mister Bean, where are you, come here later in the conversation (see the entire example 2 below), and this has no trace of stylized Indian English. The utterance means that he is looking for an advertising postcard with a picture of the TV character Mr. Bean, and it is fictitiously addressed to Mr. Bean. This is only met with Bekir's reaction niye? bøsse müsün? (English why? are you gay?), the word bøsse is Danish, while niye and müsün are Turkish. Neither is pronounced in any marked way.

This remark blocks any further excitement about Mr. Bean on Erol's side. Instead he returns to the halal and farvel point and takes it a step further. He adds the Danish word lal which means foolishness or foolish behaviour. He also adds the word hava which is Turkish for air or weather, but it is also a girl's name. The Danish goodbye greeting farvel which he has already used is taken up again. This time he pronounces it as farveller which is a Sealand Danish form. In this one moment Erol brings together a string of different types of Danish and Turkish. In addition he makes puns across styles and languages. He uses hello and goodbye to make an ironic statement about majority norms, and he develops themes both high and low in one short utterance.

Erol: Mister Bean where are you come here. Bekir: niye? bøsse müsün? [why? are you gay?] 
Erol: bir tane daha bulursanı bana verin ha bir tane daha bulursanız [if you find one more then give it to me, man, if you find one more].

Hüseyin: düşünürüz [we will think about it].

Erol: ah halalla farveller istiyor musun lan hava halal [oh halalla goodbyes do you want it, man, air halal].

Wordplay across languages appears in other cases, such as an utterance which was also produced by Erol: mit største mareridt er at fange muser Musa (English my worst nightmare is to catch mouses Musa), see example 3 below. The form muser is non-standard. The standard has mus both in the singular and the plural, and the form muser will generally be considered child language, or perhaps learner language, neither of which pertains to Erol. He pronounces the form muser exactly like the (Turkish) boy's name Musa. This is a cross-linguistic pun - Hüseyin repeats the pun and laughs, and Bekir's subsequent negative reaction shows us that the pun is indeed a pun and not a slip of the tongue.

Erol: mit største mareridt er at fange muser Musa [my worst nightmare is to catch mouses Musa].

Hüseyin: Musa fange muser [Musa catch mouses]. (Hüseyin laughs)

Bekir: eşeklik yapma ya [don't be stupid now].

These very brief excerpts from a much longer conversation (conversation 903 of the Køge project) are sufficient to demonstrate how difficult it would be to count the number of codes used by Erol. Within Danish there are at least standard Danish, Sealand Danish, and late modern urban youth style. All of these are associated with evaluations and stereotypes. These evaluations are clearly employed by Erol in some of the examples - while in other examples he seems to oppose the evaluations we find in Danish society at large (for instance, the negative evaluations of halal and of young Moslem men, as they are related to the late modern urban youth style). In addition we find his non-marked English (as close as he gets to a standard) as well as stylized Asian English. And we have not even considered the variation within his Turkish. We can characterize the features which ap- 
pear in these examples, and we can connect them to notions of specific codes. But we can not characterize Erol as anything but polylingual in the sense defined above.

\section{Conclusions}

The basis of a model of bilingualism must be the linguistic features (units, rules). Features are socioculturally associated with sets of features called "languages" (or, sometimes in a more nuanced line of thinking, "dialects"). This happens in accordance with an ideology originating in European National Romanticism, and the process is therefore very strong and should be accounted for in any sociolinguistic model of bilingualism. The association of features with "languages" and "dialects", i.e. "codes" leads many speakers to the view that the features should also be separated. This is the view which prevails in educational systems, particularly in language classes.

The feature-based concept of language combines with the concept of association to ideologically determined "languages" or "dialects" (i.e. codes) to a definition of code-switching. This definition is possible because features are associated with different codes, and interlocutors (may) agree that the features are associated with different codes.

The integrated bilingualism norm allows code-switching between codes known to the speaker (while the criteria of "knowing" are still unclear). However, many speakers follow an entirely different norm in their actual behaviour, namely the polylingualism norm. This norm also covers the cases where speakers more or less routinely use features from languages which they don't "know". Such behaviour is not very special - in fact most people do it, if "only" involving different "dialects" belonging to their one "language".

What distinguishes people considered "multilingual" from people considered "monolingual" is not such behaviour. The difference lies in the range of different socioculturally determined sets of features, the range of codes, from which the speakers have access to features. "Monolinguals" hardly exist in late modern urban contexts, if "monolingual" means "a person who knows features ascribed to one and only one language". Monolingualism and bilingualism can only be upheld as meaningful concepts 
if we specify a relationship between the speaker and the ideologically constructed sets of features. Educational systems struggle with such criteria (curriculum goals etc.) - and while doing so and insisting on monolingualism norms, the educational systems are far away from the reality of the late modern urban youth and its language practices. This reality is polylingual.

\section{Addresses:}

Jens Normann Jørgensen

University of Copenhagen

Njalsgade 120

DK-2300 Copenhagen S

Denmark

E-mail: normann@hum.ku.dk

Somogy Varga

E-mail: varga@hum.ku.dk

\section{References}

Arnfast, Juni Söderberg and Jens Normann Jørgensen (2003) “Code-switching as a communication, learning, and social negotiation strategy in firstyear learners of Danish". International Journal of Applied Linguistics $13,1,23-53$.

Auer, Peter (1995) "The pragmatics of code-switching: a sequential approach". In Lesley Milroy and Pieter Muysken, eds. One speaker, two languages: cross-disciplinary perspectives on code-switching, 115-135. Cambridge: Cambridge University Press.

Boyd, Sally (1985) Language survival: a study of language contact, language shift and language choice in Sweden. Göteborg: University of Göteborg.

Christensen, Mette Vedsgaard (2004) “Arabiske ord i dansk hos unge i multietniske områder i Århus”. In Christine B. Dabelsteen and Juni Söderberg Arnfast, eds. Taler de dansk? Aktuel forskning i dansk som andetsprog, 33-52. (Københavnerstudier i tosprogethed bind, 37.) København: Københavns Universitet.

Gumperz, John J. (1982) Discourse strategies. Cambridge: Cambridge University Press.

Hacking, Ian (1999) The social construction of what? Cambridge, Massachusetts and London: Harvard University Press. 
Heller, Monica (2007) "Bilingualism as ideology and practice". In Monica Heller, ed. Bilingualism: a social approach, 1-22. Basingstoke, Hampshire: Palgrave Macmillan.

Hewitt, Roger (1991) "Language, youth and the destabilisation of ethnicity". In Cecilia Palmgren, Karin Lövgren, and Göran Bolin, eds. Ethnicity in youth culture, 27-41. Stockholm: Stockholm University.

Hinnenkamp, Volker (2003) "Mixed language varieties of migrant adolescents and the discourse of hybridity". In Jens Normann Jørgensen, ed. Bilingualism and social relations: Turkish Speakers in north-west Europe, 12-41. Clevedon, Avon: Multilingual Matters.

Hudson, Richard A. (1996) Sociolinguistics. 2nd ed. Cambridge: Cambridge University Press.

Jacquemet, Marco (2005) "Transidiomatic practices: language and power in the age of globalization". Language \& Communication 25, 257-277.

Jørgensen, Jens Normann (2001) "Multi-variety code-switching in conversation 903 of the Køge Project”. In Jens Normann Jørgensen, ed. Multilingual behavior in youth groups. Scandinavian studies in the simultaneous use of two or more languages in group conversations among children and adolescents, 117-137. (Copenhagen Studies in Bilingualism, the Køge Series, K11.) Copenhagen: The Danish University of Education.

Jørgensen, Jens Normann (2004a) "Languaging and languagers". In Christine

B. Dabelsteen and Jens Normann Jørgensen, eds. Languaging and language practices, 5-23. (Copenhagen Studies in Bilingualism, 36.) University of Copenhagen.

Jørgensen, Jens Normann (2004b) "Bilingualism in the Køge project". International Journal of Bilingualism 7, 4, 333-352.

Jørgensen, Jens Normann (2010) Languaging. Nine years of polylingual development of young Turkish-Danish grade school students. 2 vols. (Copenhagen Studies in Bilingualism, K15-K16.) University of Copenhagen.

Makoni, Sinfree and Alastair Pennycook (2006) "Disinventing and reconstituting languages". In Sinfree Makoni and Alastair Pennycook, eds. Disinventing and reconstituting languages, 1-41. Clevedon, Avon: Multilingual Matters.

Møller, Janus Spindler and Jens Normann Jørgensen (2008) "Poly-lingual languaging in peer group interaction". Nordand 3, 2, 39-56.

Nortier, Jacomine (2001) “'Fawaka, what's up?' Language use among adolescents in monoethnic and ethnically mixed groups". In Anne Hvenekilde and Jacomine Nortier, eds. Meetings at the crossroads. Studies of multilingualism and multiculturalism in Oslo and Utrecht, 61-72. Oslo: Novus. 
Quist, Pia (2000) 'Ny københavnsk 'multietnolekt'. Om sprogbrug blandt unge i sprogligt og kulturelt heterogene miljøer”. Danske talesprog 1, 143-211.

Rampton, Ben (1995) Crossing: language and ethnicity among adolescents. London and New York: Longman.

Romaine, Suzanne (1994) Language in society: an introduction to sociolinguistics. Oxford: Oxford University Press.

Sweetland, Julie (2002) "Unexpected but authentic use of an ethnically-marked dialect". Journal of Sociolinguistics 6, 4, 514-538.

Undervisningsministeriet (1992) Sproglig viden og bevidsthed. (Kvalitet i uddannelse og undervisning. KUP-rapport, 16.) København: Undervisningsministeriet.

\begin{abstract}
Kokkuvõte. Jens Normann Jørgensen ja Somogy Varga: Normid ja praktikad paljukeelses käitumises. Sotsiolingvistiline mudel. Artiklis käsitletakse mõistete „keel kui kategooria“ ja „konkreetne keel" suhteid. Väidame, et kontseptsioon keeltest kui selgelt eristuvatest ja loendatavatest ühikutest on ideoloogiline konstruktsioon. Selline ideoloogiline konstruktsioon teenis Euroopa rahvusriike väga hästi romantismiperioodil ja hiljem, näiteks kolonialismi ajal (vt näiteks Heller 2007, Makoni ja Pennycook 2006). Rahvusvahelistumise hoogustumisega on selline kontseptsioon keeltest sattunud üha enam vastuollu uurijate keelekogemusega terves Euroopas. Tegelikult ei ole sotsiolingvistid kunagi nõustunud sellega, et keeli saab vaadelda näiteks murretest eraldi. Igasuguse konkreetse keele, näiteks hollandi keele mõiste on sotsiokultuuriline konstruktsioon ning see eksisteerib ainult normide tasandil. Keelekasutuse tasandil ei saa me sellist keelte kontseptsiooni järgida. Pakume alternatiivina ideed, et keelekasutuse kirjeldused ja analüüs peaksid põhinema mitte „keeltel“, vaid tunnustel, ning keskenduda tuleks rääkijale (Hudson 1996).
\end{abstract}

Märksõnad: keeleline eneseväljendus, paljukeelsus, keelenormid, tänapäeva linnanoorte keel 